\title{
Los videos en la red y el net-art
}

\section{Videos on the web and the net-art}

\section{Pawel Anaszkiewicz}

ORCID: 0000-0003-2330-1490/pawelanasz@hotmail.com

Profesor-investigador, Facultad de Artes, Universidad Autónoma del Estado de Morelos (UAEM)

\section{RESUMEN}

Los videos compartidos en la red son una etapa reciente en el desarrollo de nuestra cultura mediática. Aunque muchos de los creadores y espectadores de videos en línea los consideran como objetos de una actividad personal cotidiana, con las fronteras desdibujadas entre el arte y el archivo de la memoria, el simple hecho de estar presentes en internet los ubica en la esfera de la comunicación social. La práctica de ver videos en internet involucra la lectura de contenidos simultáneos, como textos e imágenes, por ejemplo, cuando el video está incrustado en un artículo periodístico o en medio de imágenes fijas que se alternan con escenas en movimiento de anuncios publicitarios. La experiencia de lectura en computadora mezcla muchas veces esta información con imágenes simultáneas desplegadas en distintas zonas de la pantalla. Para el usuario de internet, observar una imagen completa de un objeto temporal o de una imagen fija, en la práctica es una excepción. En palabras de Andreas Treske, la característica esencial del video en línea es que éste nunca existe solo.

\section{PALABRAS CLAVE}

net-art, videos, internet, imágenes, comunicación
ABSTRACT

The videos shared on the web are a recent stage in the development of our media culture. Although many of the creators and viewers of online videos consider them as objects of a daily personal activity, with the blurry borders between art and the archive of memory, the simple fact of being on the internet places them in the circle of social communication. Watching videos on the Internet involves reading simultaneous content, such as texts and images, for example, when the video is embedded in a newspaper article or in the middle of still images that alternate with moving scenes of commercials. The computer reading experience often mixes this information with simultaneous images displayed in various areas of the screen. For the internet user, observing a complete image of a temporary object or still image is an exception in practice. In the words of Andreas Treske, the essential characteristic of an online video is that it never exists alone.

\section{KEY WORDS}

net-art, videos, internet, images, communication 


\section{De los inicios de internet al videoblog}

Internet es una red mundial de conexión entre ordenadores que despegó entre los usuarios particulares en los años noventa del siglo pasado, a partir de las redes locales que ya existían desde la década de 1960. Entre los investigadores existe una disputa acerca de sus inicios y las primeras redes locales que lo habilitaron. En su libro Inventing the Internet, Abbate (2000) discute sobre algunas de las primeras redes locales, dándole primacía, en las etapas iniciales de internet, al grupo de científicos que trabajó en Suiza en el CERN (Conseíl Européen pour la Recherche Nucléaire).

En sus inicios, internet funcionaba con sitios de boletines informativos en los que se subían documentos e imágenes fijas. Los siguieron las wikis, páginas web y los blogs, que los mismos usuarios podían editar. Se puede pensar que estos formatos ayudaron en el proceso de transformación de los lectores pasivos en usuarios activos de internet. Estas formas de interacción en la red fueron los antecedentes de los videoblogs, que surgieron por primera vez en al año 2000 (Berry, 2014).

La idea de comunicación es fundamental para la estética digital del videoblog, incluso más ahora, cuando está presente también en las pantallas de los teléfonos móviles. Bishop (2012) se pregunta si se puede realizar arte a partir de la comunicación en internet:

En 2001, Lev Manovich notó de manera provisoria que, al poner en primer plano la comunicación en dos sentidos como actividad cultural fundamental (en oposición al flujo en un solo sentido en una película o en un libro), el internet nos pide reconsiderar el mero paradigma del objeto estético: ¿Puede la comunicación entre los usuarios convertirse en un objeto estético? (s/p).

\section{Los eventos digitales y el net-art}

La práctica de ver videos en internet involucra casi siempre la lectura de contenidos simultáneos de textos e imágenes. Por ejemplo, cuando el video está incrustado en un artículo periodístico o en medio de las imágenes fijas que se alternan con escenas en movimiento en anuncios publicitarios. Para el usuario de internet, observar una imagen completa de un objeto temporal en la práctica es una excepción. Esta particularidad del video en la red Treske (2013) la describe de la siguiente manera: "Cualquier cosa que aparece o se junta con un video en línea, tanto en la misma página, dentro de mismo grupo de datos, en la base de datos compartida, como en la red, apunta a esta característica esencial del video en línea: nunca existe solo" (p. 11).

Al menos está formando un dúo, el video y su enlace. Esta pareja crea un espacio mínimo de signos e imágenes en movimiento y existen programas que permiten transformarlos de manera inmediata. Por ejemplo, al insertar un vínculo de Google Maps se muestra el lugar 
donde ocurrió un suceso que grabamos con nuestro teléfono. Estas operaciones se pueden efectuar en línea, permitiendo así que la red y sus datos sean parte de nuestro video. Este procesamiento no lineal de los datos digitales denota varios ciclos de programación que no componen el video como su salida final, sino más bien un ambiente para su visualización.

Esto que acabamos de describir, la operación realizada sobre un video en internet, Treske (2013) la define como el proceso de engrosar la imagen. Así, un evento digital en la red se puede definir como un video en línea, junto con todos sus enlaces, referencias y transformaciones de datos digitales.

En una ingeniosa e irónica obra de arte en la red titulada Dance with us (figura 1), el artista francés Grégory Chatonsky creó una burbuja de datos alrededor de un video engrosando su imagen, según la terminología de Treske. Al crear esta pieza, el autor se apropió de una secuencia de la película Shall We Dance, de 1937, donde Fred Astaire ejecuta un baile sobre la cubierta de un barco. El video de este corte fílmico está vinculado, en tiempo real, con la actividad de la Bolsa de Valores de Estados Unidos, cuyos cambios en el índice comercial influyen en la velocidad de reproducción del video. Si la actividad comercial es más volátil, si las transacciones en el mercado son más aceleradas, Fred Astaire baila de manera más fluida. Tanto en la página de internet como en su versión para exposición en galería (figura 1), junto a la secuencia del baile de Fred Astaire controlado por el mercado, se expone el dato numérico de la Bolsa de Valores, que se actualiza en tiempo real por medio de internet.

\section{Figura 1}

\section{Foto de la videoinstalación de la red Dance with us}

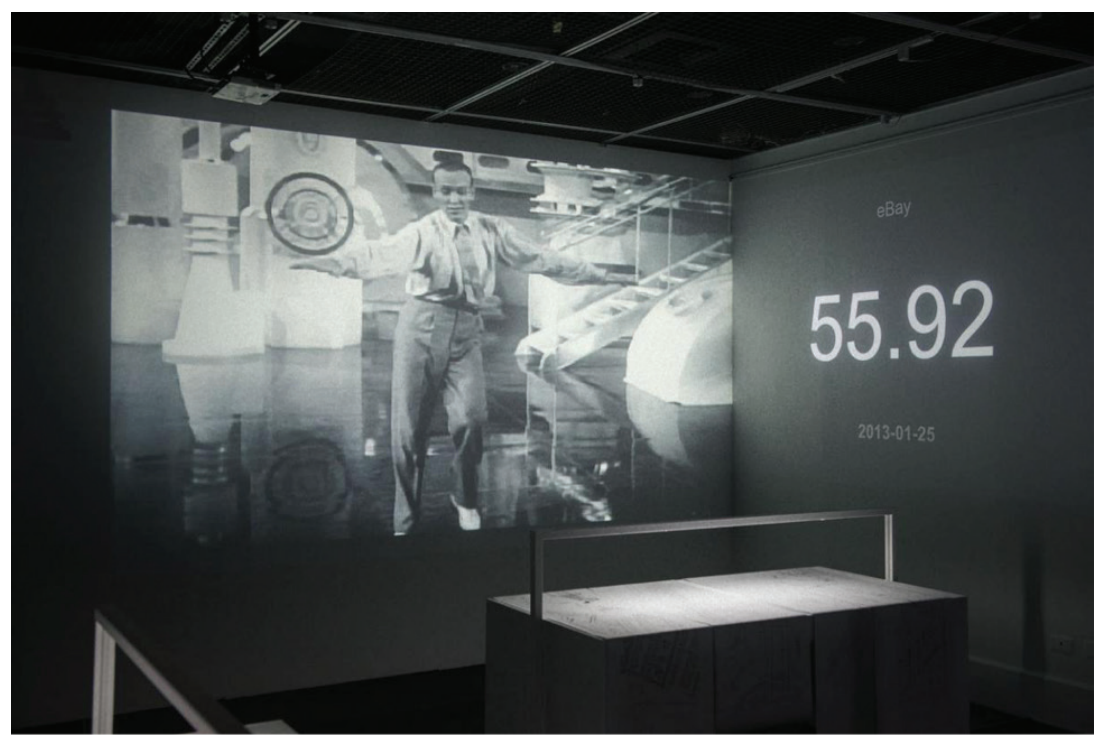

Fuente: Chatonsky (2008).

Año 16, núm. 40, noviembre 2020-marzo 2021 
En otra obra de net-art, Netsea (figura 2), de Chatonsky, monitorea los mensajes que circulan en la red en tiempo presente. Es una máquina de extracción de sentimientos, a partir del flujo de los comunicados en la red local de internet, cercana a la galería donde se presenta. El autor afirma que, para tal fin, utiliza un software de espionaje del FBI para el monitoreo de comunicaciones electrónicas. Los eventos digitales captados son traducidos en la imagen de la superficie ondulante de un océano artificial. De este "mar de datos" se extraen los comunicados relacionados con los sentimientos y se presentan de forma escrita sobre la imagen del océano, a la vez que son leídos con la voz de un sintetizador. Como dice Waelder (2010) en un artículo publicado en el Journal of Media Culture, una revista digital australiana: "El murmullo de datos se convierte en la historia misma sin guía de un narrador" (pp. 164-165).

Figura 2

Foto de la obra mediática Netsea

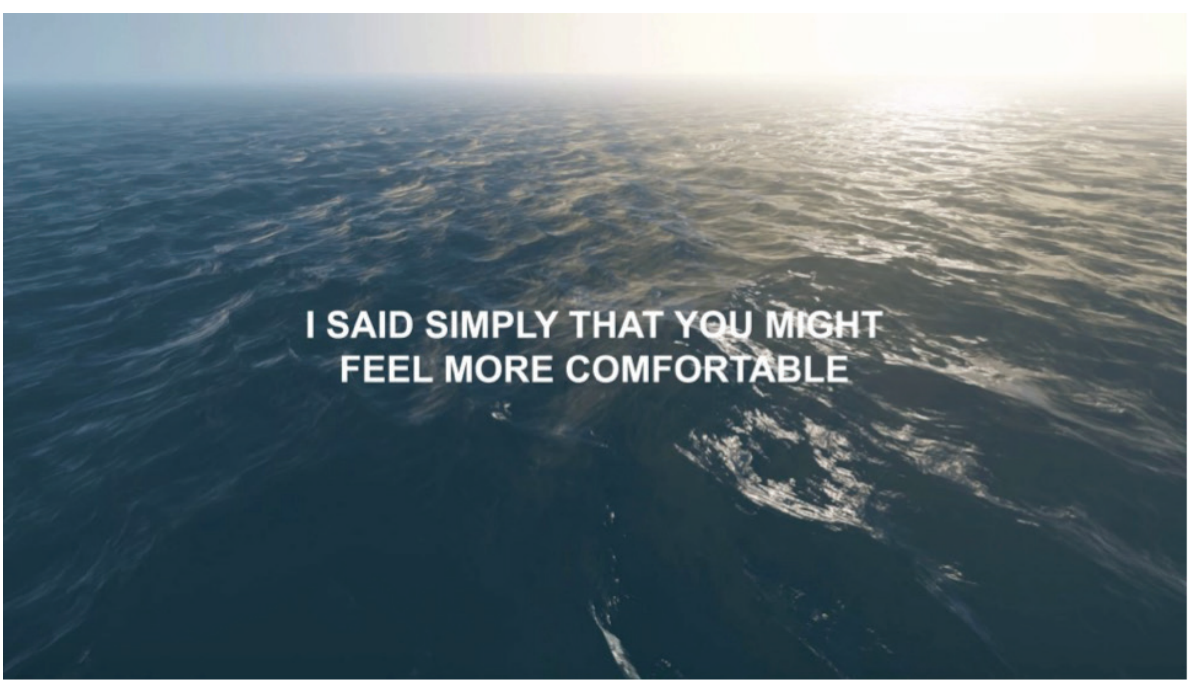

Fuente: Chatonsky (2015)

Al comentar sus propias obras de net-art, Chatonsky desarrolló el concepto de Flussgeist [espíritu de flujo] (Chatonsky, 2007), que designa mejor, según él, nuestros tiempos de flujos y cambios constantes, que el concepto de Zeitgeist [espíritu del tiempo], determinado más por la Historia. Una de sus exposiciones de net-art se titulaba Flussgeist: The Spirit of the Network (Chatonsky, 2009) [Flussgeist: El espíritu de la red], una serie de videos $\sin$ fin que se generaban a partir de los datos que entraban desde la red en tiempo real.

Su autor dice que no fue un dispositivo de interface de los datos visuales de la red, sino un sitio que generaba ficciones a partir de flujos de los eventos digitales en internet. En muchas de sus obras, Chatonsky nos muestra que los datos transmitidos en internet no son solamen- 
te series de señales digitales con valores de cero y uno, sino fragmentos de nuestras experiencias y sentimientos, los cuales revelan así el espíritu de nuestro tiempo como flujos de los afectos en internet (Waelder, 2011).

\section{Los videos en la red como esferas de interacción social}

Los videos en forma de proyecciones son vistos de vez en cuando en las galerías y museos, pero con la tecnología de internet y los teléfonos móviles se convirtieron en acompañantes de la vida diaria para muchos de nosotros. El video, visto antes sólo como un tipo de tecnología mediática, en la actualidad se ha vuelto también una esfera de interacción social. Esta actividad la promueven las mismas redes, preguntando automáticamente si queremos compartir tal video, imagen o mensaje. Vistos así, los videos en línea son medios de socialización que crean "esferas artificiales de existencia" (Treske, 2013, pp. 29-30).

En internet, las personas comparten no solamente las grabaciones de acontecimientos de su vida privada sino también videos subidos por otros, acompañados por comentarios, diálogos, citas y opiniones, en un momento vividos colectivamente, con lo cual se crean "burbujas" autoanimadas de convivencia social. La participación en estas "burbujas" de videos es, en la mayoría de los casos, voluntaria. En cualquier momento, por falta de participantes, la esfera termina su vida como si se tratara de una burbuja de jabón.

Al participar en estas esferas de videos en internet tenemos también libertad de reeditar y compartir nuestras grabaciones, expandiendo así el espacio y la temporalidad de su existencia. Los eventos que compartimos no son necesariamente personales; pueden ser políticos, como vimos en el caso de los eventos relacionados con la primavera árabe, o pueden corresponder a movimientos de protesta, como por ejemplo el Occupy Wall Street, movimiento sin líderes que convocaba, en 2011, por medio de internet, a las protestas contra la evasión fiscal de las grandes empresas en Estados Unidos. Algunos participantes de estas esferas de videos graban y transmiten imágenes por medio de teléfonos móviles; otros los ven y comparten. A veces estas esferas de interacción social crecen como bolas de nieve, formando una avalancha de videos que se expande de manera viral, creando esas burbujas instantáneas.

Según las estadísticas de la plataforma YouTube, $95 \%$ de los videos vistos en internet son videos musicales (Osman, 2019) y los usuarios más activos de esta red social, que entran en esta plataforma al menos una vez al día, son personas con edades entre once y quince años (Mohsin, 2020), lo que nos dice mucho sobre el perfil de los usuarios masivos de internet: son adolescentes susceptibles de seguir las modas de los ritmos populares del momento.

Como ejemplo basta con recordar una burbuja de interés que creció entre la comunidad de internet en 2017, con el video musical titulado Despacito (figura 3), del cantante puertorriqueño Luis Fonsi, que tiene más de siete mil millones de reproducciones en YouTube. Se logró un récord histórico, si tenemos en cuenta algunos datos estadísticos recientes: en 
septiembre de 2020 había en el mundo aproximadamente 4.9 mil millones de usuarios de internet. De ellos, 51.8\% se encontraban en Asia, solamente 14.8\% en Europa, 9.5\% en América Latina y el Caribe, y menos de $7 \%$ en Estados Unidos (Internet World Stats Usage and Population Statistics, 2020).

Figura 3

Captura de pantalla del video musical Despacito, por Luis Fonsi

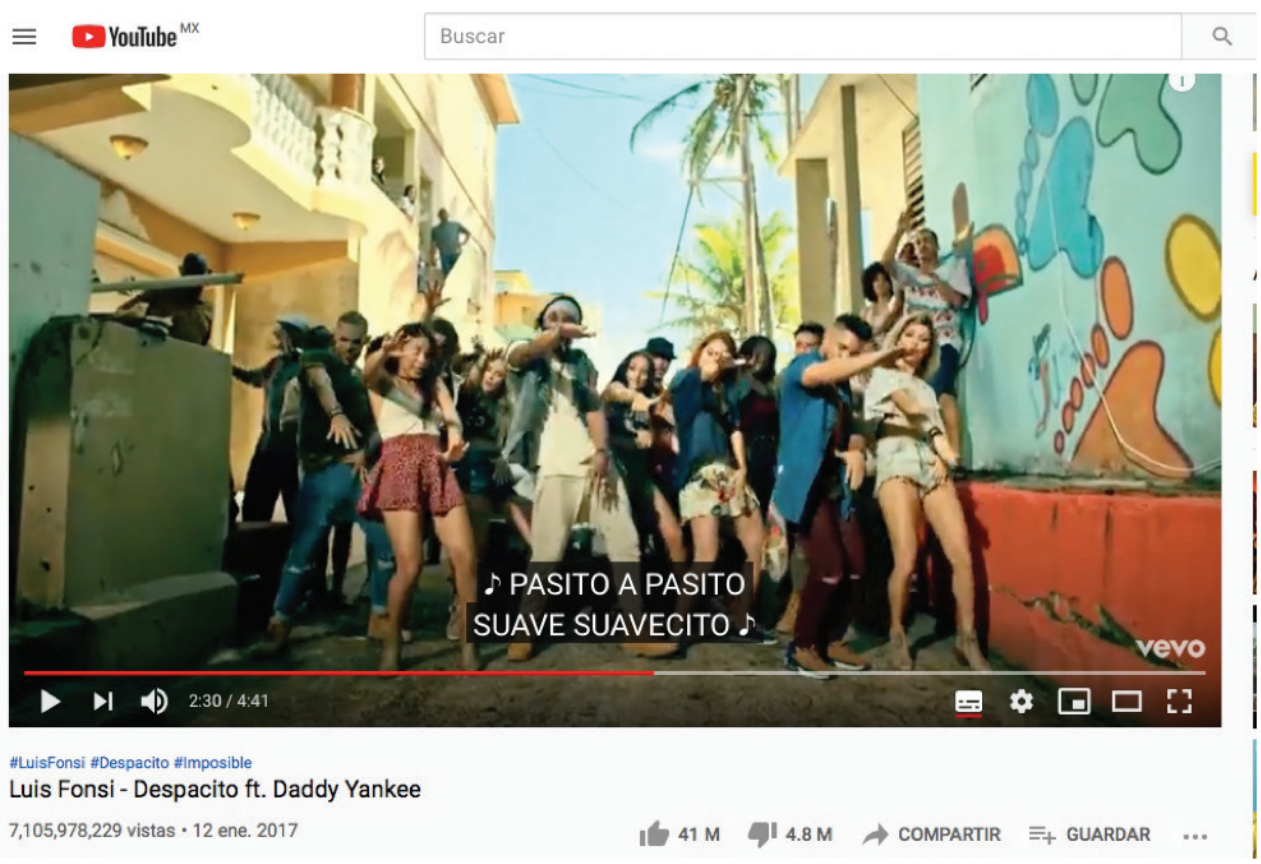

Fuente: Fonsi (2017).

Robrecht Vanderbeeken acuñó un término relacionado con la conciencia individual de los navegantes en internet: Eclipsing [eclipsar] (Vanderbeeken, 2011). Lo describe como una manera de opacar la realidad experimentada por una persona mediante otra realidad, moldeada por los medios audiovisuales en general y por videos en línea en específico. Las pantallas exponen lugares y personas nunca antes visitados o confrontados.

Si esta visita o encuentro nos sucediera en la vida real nos parecería poco natural. Vanderbeeken (2011, p. 37) presenta además otro término vinculado con los medios: truth procedure [procedimiento de veracidad]. Lo que es suficientemente visible en las noticias parece tener una presencia real y ser verídico. De manera opuesta, aquello que no se publica o no se muestra en los medios es poco confiable. De estas afirmaciones de Vanderbeeken se desprende que las pantallas de teléfono, computadora o televisor se consideran actualmente plataformas de una autoridad máxima.

Año 16, núm. 40, noviembre 2020-marzo 2021 
La nueva conciencia colectiva sobre los objetos temporales creados por medios audiovisuales de difusión masiva ha sido estudiada también por Bernard Stiegler. En sus tres tomos titulados La técnica y el tiempo, editados originalmente en Francia entre 1994 y 2001, el autor discute la influencia de la tecnología en las humanidades. En el tercer libro de la serie, subtitulado El tiempo del cine y la cuestión del malestar (2004), Stiegler estudia los inventos tecnológicos, en particular el cine y la televisión, que transforman sin remedio las consciencias individuales y colectivas. Algo semejante a lo que ya afirmaba desde el segundo volumen de la serie:

Las industrias de programas y, más particularmente, la industria mediática de la información radiotelevisada, producen en masa objetos temporales que tienen la característica de ser oídos o mirados simultáneamente por millones, a veces decenas, centenas e incluso miles de millones de "conciencias": esta coincidencia temporal masiva domina la nueva estructura del acontecimiento a la que corresponden nuevas formas de conciencia y de inconciencia colectivas (Stiegler, 2002, p. 370).

Aunque los textos de Stiegler se refieren principalmente al cine y la televisión, podemos extrapolarlos a los nuevos entornos tecnológicos de internet como espacios, al mismo tiempo masivos e individualizados, que influyen en las consciencias de las generaciones actuales mucho más que los inventos tecnológicos anteriores.

Para Stiegler, un objeto temporal se establece cuando su flujo coincide con el flujo de la consciencia de su receptor (por ejemplo, una melodía, una película, etcétera). La industrialización de la producción y distribución de tales objetos Stiegler la identifica con la industrialización de la relación del ser humano con el tiempo, lo que resulta en la industrialización de su memoria (Stiegler, 2002, p. 151). Este proceso es peligroso en tanto que estandariza las consciencias individuales que ahora emplean los objetos temporales de distribución masiva como prótesis de sus consciencias.

Las nuevas conciencias e inconciencias individuales dan paso a las colectivas, evidentes en los nuevos movimientos sociales, que se parecen a los flujos de información audiovisual. Estos últimos se ven reforzados por la accesibilidad que proporciona la telefonía móvil. Los eventos que antes pasaban muchas veces sin dejar huella ahora viven en la esfera de la percepción de las multitudes; muchos programas informativos se alimentan de estas grabaciones subidas a la red, que en circunstancias tecnológicas anteriores eran inaccesibles para los equipos de reporteros. La acción de grabar con teléfonos móviles y la reproducción de los videos en vivo debe también parte de su impacto a la difusión en las redes.

Las videoesferas de interacción social son espacios de eventos digitales construidos por los seres humanos armados con grabadoras y difusores de medios audiovisuales. En las esferas de video, estos últimos ya no son objetos temporales discretos que se contemplan 
separados de su entorno. Sus productores, inmersos en estos espacios informáticos de múltiples puntos de entrada, navegan en ellos al mismo tiempo que los construyen, subiendo paquetes de videos junto con la información que los rodea.

El campo del arte contemporáneo que sigue siendo muy fructífero está vinculado con las interacciones sociales en internet. En el contexto de la red, el artista interviene muchas veces como mediador y se convierte en un creador de dispositivos que facilitan las relaciones sociales, creando esferas públicas autónomas (Brea, 2004). Proyectos de net-art impulsados por Antoni Abad son aquí paradigmáticos. Entre 2004 y 2016, su proyecto megafone.net (figura 4) invitaba a profesionistas que transitan por las grandes urbes, como taxistas y mensajeros, y en general personas pertenecientes a grupos socialmente marginalizados — sexoservidoras, trabajadores migrantes, gitanos, refugiados, discapacitados, entre otros-, de ciudades como Madrid, Barcelona, Ciudad de México, San Paulo, Nueva York o Montreal, a usar sus teléfonos móviles para crear grabaciones de audio, videos, textos y fotos y publicarlos inmediatamente en la página de la red que fue creada por el artista específicamente para ellos.

Figura 4

Captura de una parte de la página https://megafone.net, de acceso a proyectos inspirados por Antoni Abad, 2004-2016

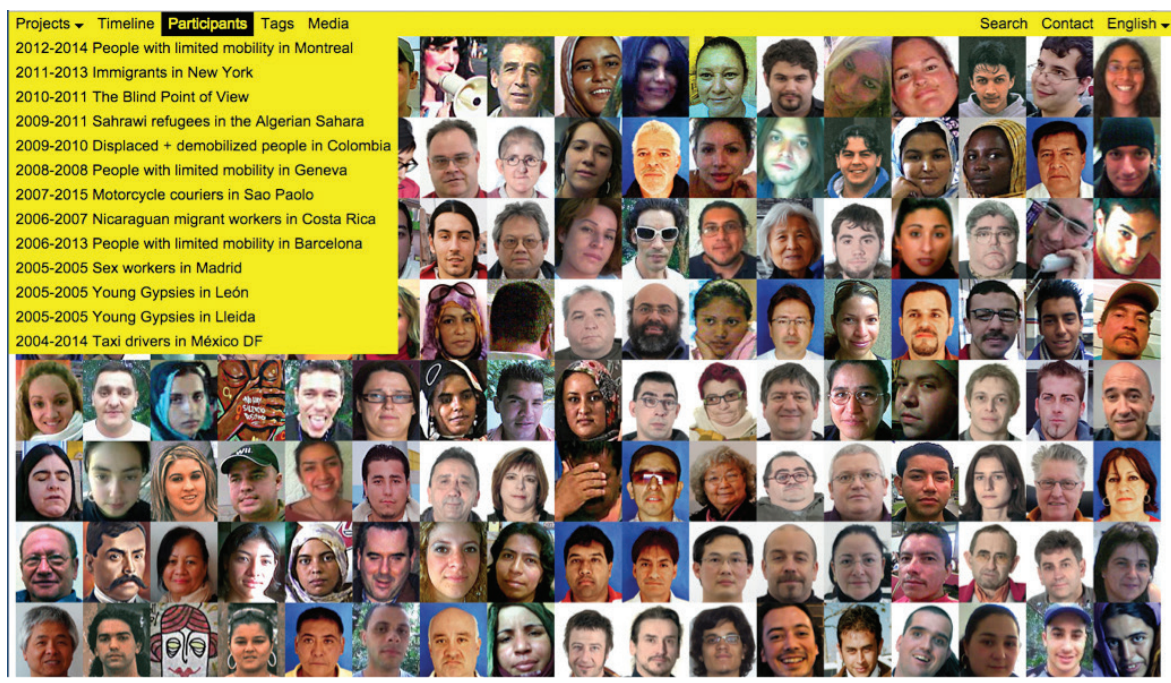

Fuente: Abad (2014).

Los participantes transformaron sus teléfonos móviles, muchas veces proporcionados por Abad, en megáfonos metafóricos para ampliar las voces de los grupos e individuos olvidados o malinterpretados en los medios masivos. Este proyecto se expuso de manera más amplia en el Museo de Arte Contemporáneo de Barcelona en 2014 (Abad, 2014).

Año 16, núm. 40, noviembre 2020-marzo 2021 


\section{Comentarios finales}

Aunque muchos de los creadores y espectadores de videos en línea los consideran objetos de una actividad personal cotidiana, con las fronteras desdibujadas entre el arte y el archivo de la memoria, el simple hecho de estar presentes en internet los ubica en la esfera de la comunicación social. Los videos compartidos en la red son una etapa reciente en el desarrollo de nuestra cultura mediática. Así la describe Manovich (2008):

podemos decir también que nos graduamos de la película/video del siglo xx y llegamos hacia el video social del principio del siglo XXI (...) [y más adelante:] (...) En cuando al típico video diario o dibujo animado japonés en YouTube, pueden no ser muy sobresalientes pero son abundantes. De hecho, en todos los medios donde las tecnologías de producción fueron democratizadas (el video, la música, la animación, el diseño gráfico, etcétera) me he encontrado con muchos proyectos que no solamente rivalizan con aquellos producidos por las compañías comerciales más conocidas y los artistas más conocidos, sino que exploran también nuevas áreas, todavía no exploradas, por lo que se les dota de grandes cantidades de capital simbólico (pp. 33-43).

La transmisión directa de la información audiovisual en tiempo real en el mundo entero, por medio del video en línea, le otorga actualmente a éste un lugar privilegiado entre los mecanismos de la comunicación. Este desarrollo tecnológico libera las condiciones para crear nuevas formas estéticas. Los proyectos de net-art se fundamentan, en buena medida, en la comunicación social mediada por videos e incentivan la creación de conciencia comunitaria entre algunos usuarios de internet, lo que ofrece una oportunidad de sensibilización sobre problemas globales y de comunidades locales al mismo tiempo, y puede motivar acciones para el cambio.

\section{Referencias}

Abad, A. (25 de julio de 2014). Megafone.net/2004-2014/. https://www.youtube.com/ watch? $=$ nlepNcjbOj4

Abbate, J. (2000). Inventing the Internet. Cambridge: Massachusetts Institute of Technology.

Berry, T. (2014). The Film of Tomorrow: A cultural History of Videoblogging. Berry, T. (2014). The Film of Tomorrow: A cultural History of Videoblogging. [Tesis doctoral, Universidad de Sussex]. http://sro.sussex.ac.uk/id/eprint/53713/

Bishop, C. (2012). Digital Divide: Contemporary Art and New Media. Artforum. https://www. artforum.com/print/201207/digital-divide-contemporary-art-and-new-media-31944

Brea, J. L. (2004). El tercer umbral. Estatuto de las prácticas artísticas en la era de capitalismo cultural. CENDEAC. 
Chatonsky, G. (2007). Flux: entre fiction et narration. http://chatonsky.net/flux-entre-fictionet-narration/

Chatonsky, G. (2008). Dance with us. http://chatonsky.net/dance-with-us/

Chatonsky, G. (2009). Flussgeist: The Spirit of the Network. http://chatonsky.net/flussgeist/

Chatonsky, G. (2015). Netsea. http://chatonsky.net/netsea/

Fonsi, L. (12 de enero de 2017). Luis Fonsi - Despacito ft. Daddy Yankee [Captura de pantalla]. Youtube. https://www.youtube.com/watch?v=kJQP7kiw5Fk

Internet World Stats. Usage and Population Statistics (30 de septiembre de 2020). Internet Users Distribution in the World-2020 Q3. https://www.internetworldstats.com/stats.htm

Manovich, L. (2008). The Practice of Every (Media) Life. En Lovink, G. y Niederer, S. (eds.), Video Vortex Reader, Responses to YouTube. Institute for Networked Cultures (pp. 33-43).

Mohsin, M. (5 de febrero de 2020). Estadísticas youtube 2021 [infografía]-10 datos fascinantes de youtube. Oberlo. https://www.oberlo.com.mx/blog/estadisticas-youtube

Osman, M. (6 de septiembre de 2019). Estadísticas y datos impresionantes del YouTube (EI segundo sitio más visitado). Kinsta. https://kinsta.com/es/blog/estadisticas-youtube/

Stiegler, B. (2002). La técnica y el tiempo II. La desorientación. Hiru Argitaletxea.

Stiegler, B. (2004). La técnica y el tiempo III. El tiempo del cine y la cuestión del malestar. Hiru Argitaletxea.

Treske, A. (2013). The Inner Life of Video Spheres. Institute of Network Cultures.

Vanderbeeken, R. (2011). Web Video and the Screen as a Mediator and Generator of Reality. En Lovink, G. y Miles, S. R. (eds.), Video Vortex Reader II:Moving Images Beyond YouTube. Institute of Network Cultures (p. 36).

Waelder, P. (2010). The Constant Murmur of Data. M/C Journal, 13 (2). https://doi.org/10.5204/ mcj. 228

Waelder, P. (30 de marzo de 2011). El flujo de datos, una ficción en la red. Arte y cultura digital. http://laboralcentrodearte.uoc.edu/?p=1567 